\title{
Le Corbusier's Maisons Sans Lieu. Reconstructive Redrawing, Digital and Physical Model of Unbuilt Architecture
}

\author{
Ana Tagliari \\ Wilson Florio
}

\section{Abstract}

This research analyzed nine examples of unbuilt architecture conceived by Corbusier between the years 1916 to 1953, the maisons sans lieu. In this paper we present the analysis of Maisons montée à sec (1940) and Maison type La Rochelle (1953), minimal houses to be built in series, a constant theme in the research of Le Corbusier. The investigation of the internal spaces of the residences was developed by diagrammatic drawings and physical models, which were built from computer drawings and digital fabrication by laser cutting and 3D printer, revealing the new technology in support to architectural representation and analysis.

\section{Keywords}

unbuilt architecture, reconstructive physical modeling, digital context, Le Corbusier.

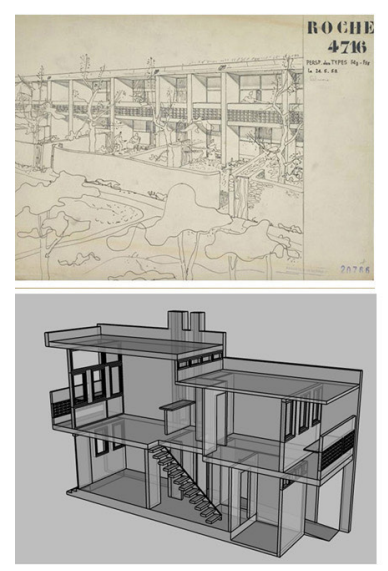

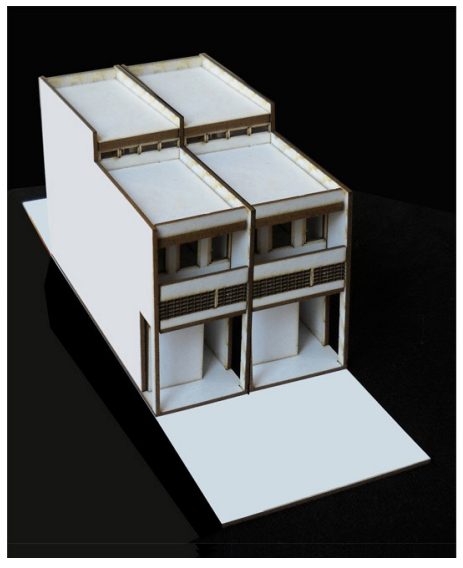

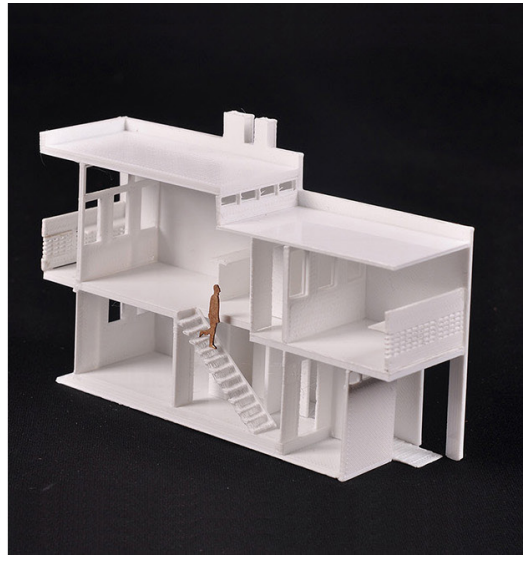

doi.org// 0.3280/oa-693.65 


\section{Introduction}

Research on serial construction, prefabrication, new technologies, and new materials in housing design were topics of interest to Le Corbusier. In the 1910s, Corbusier expressed through his research his interest in developing a new way of designing and building.

After 19|4, Corbusier developed architectural works, based on research and references. The problem of housing constituted the absolute core of Le Corbusier's early works, both practical and theoretical, as noted by Sigfried Giedion [2004, p. 55 I]. The modern neighborhood of Frugès (1924-1925) in Pessac was an important opportunity for the architect to materialized his previous proposals, such as Maison Citrohan (1920), Dom-ino (1914), and Monol (1919), as well as concepts discussed and presented in his book Vers une architecture (1923). The Dom-ino system, of 1915, provided for a low-cost building system with an independent structure made up of columns and flat reinforced concrete slabs. Corbusier was already outlining low-cost serial production in his plans and research.

In this context, Curtis [1986, p. 7I] analyzes that the projects of private houses were like experimental laboratories, regarding Corbusier's project and research: "The house might even be an allegory containing the dream of the new city in miniature". Each project presents its uniqueness in an advance of experiments and research in design and construction of modern life. Curtis notes that Corbusier's home sites and designs were not standardized, and his clients were notable and unique people.

There was a need for a literature review on Le Corbusier's architecture and on the analysis of unbuilt projects in digital contexts (Larson 2000; Galli, Mühlhoff 2000; Sdegno 2008, 20 I I; Foscari, 20 I0; Maggio 20 I7; Spallone 20 I7). Several research and publications involving the study of this important architect were developed. Some authors were selected as reference, such as William J.R. Curtis, Willy Boesiger, Oscar Stonorov and Stanislau von Moos, Steven Park, Jean-Louis Cohen, Colin Rowe, among others. And, above all, the careful reading of the texts written by the architect himself were of great importance.

In this research, we analyzed a set of nine projects from 1920 to 1953. Projects with no defined location were selected, because, as a presupposition of this research, this characteristic leads us to believe that there was greater freedom of creation since there were no limiting conditions established by the location. In addition, we observed in the selected projects that the architect studied solutions, spaces, shapes, and concepts related to the development of his research on the subject of minimum housing and serial construction, which deserve to be investigated.

This text aims to reveal the results of a research that analyzed the residential projects of minimum unit to be built in series, unbuilt and without defined place, designed by Le Corbusier.
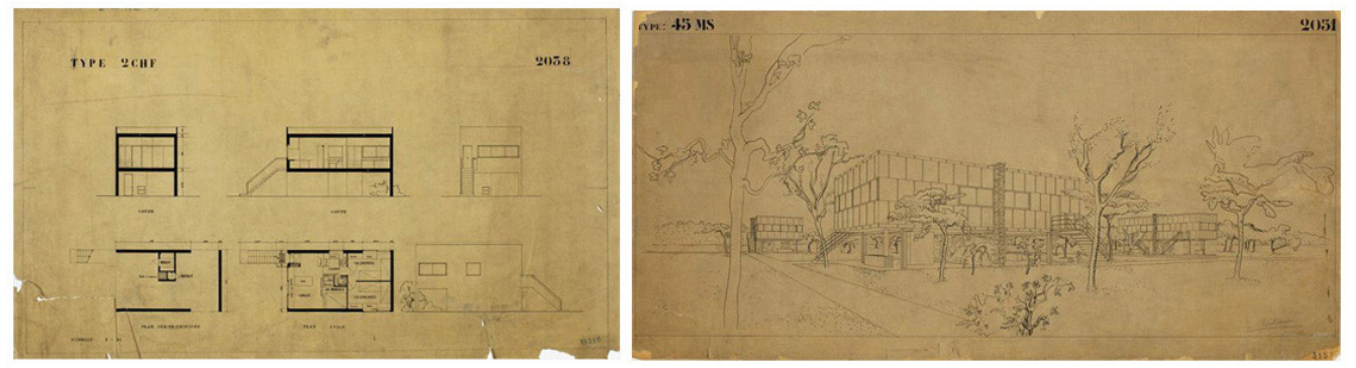

\section{Methodology}

The research analysed the folowed projetcs: Maison Ouvrières en série (1920), Maison d'artiste (1922), Maison en serie pour artisans (1924), Maison Minimum (1926), Maison Loucheur (1929), M.A.S. - Maisons montée à sec (1940), Unité d'habitation transitoires (1944), Maison Murondins (1949), and Maison type La Rochelle (1953). In this text we present the analysis of two projects which presents the possibilities of combination: Maisons montée à sec (1940) 

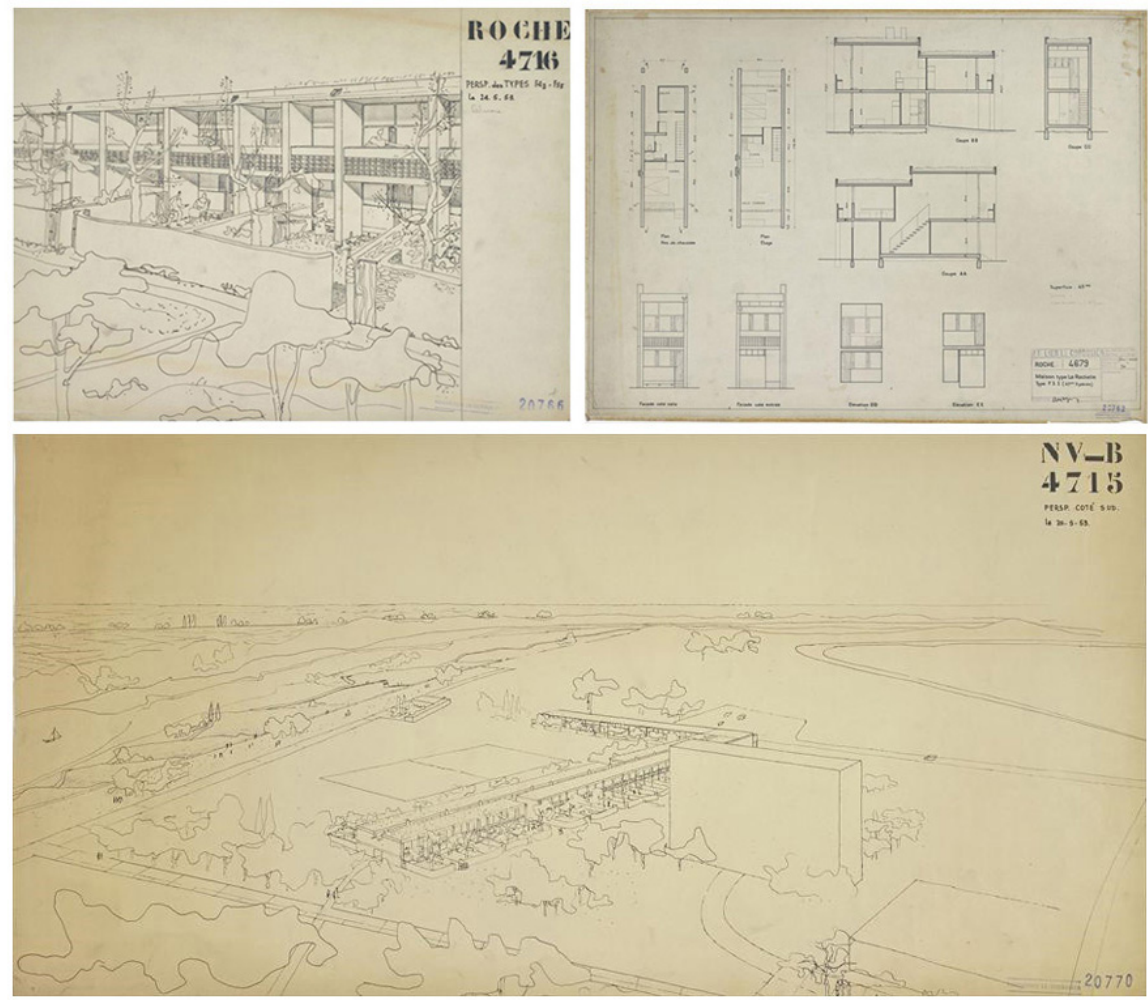

and Maison type La Rochelle (1953). From the original drawings (figs. I, 2) available on the Fondation Le Corbusier website, to the physical models (fig. 3) produces in this research thanks to new digital technologies.

These are minimum housing units designed to be built in series, a constant theme in Le Corbusier's research. The investigation of the space and form of these projects was developed through analytical drawings, diagrams, digital and physical models, which were built from digital contexts, with drawings and digital fabrication, laser cutter, and 3D printer, exploring the new technologies in favor of architectural representation and design analysis. The act of redesign has become fundamental in this analysis, and it also reveals itself as a metaphor as the research focused on the analysis of unbuilt, little-known projects.

To investigate the selected projects, some methodological procedures were adopted: I. Research and organization of project data (texts; sketches; drawings; images); 2. Interpretation of the projects; 3.Visit to Corbusier's built works, especially residences and collective housing buildings such as Marseille and Firminy, to understand space and form as well as the solutions proposed by the architect; 4. Redrawn of the projects; 5. Production of 2D and 3D drawings; Preparation of digital models, prototypes, construction of physical scale models; 6. Generation of files for production; 7. Construction of physical models; 8. Analysis of the projects through diagrams and models; 9 . Results discussion. These artifacts allowed us to analyze the form, space, and concepts of the projects, as well as the constructive elements.
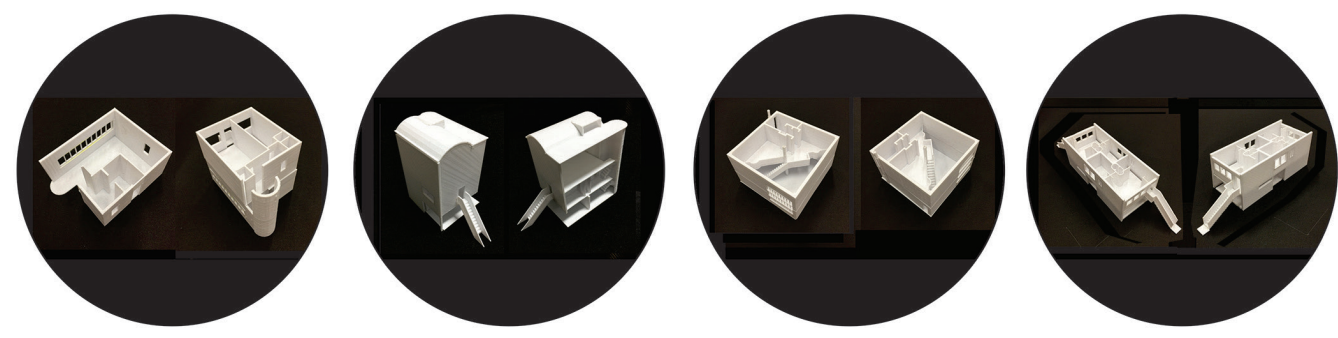


\section{Case Studies: results \& analysis}

Since the 1910s, Le Corbusier had been conducting research on the collective housing project for serial construction. The idea of building prefabricated elements came from his interest in creating a project that could be built cleanly, quickly, and economically.

\section{Maisons Montée à Sec (1940)}

The idea behind the Maison montée à sec project (fig. I) arose in the 1920s from studies for construction with prefabricated elements that would allow a quick, clean, and practical 'dry' construction at the construction site.

The Maison Loucheur (1929) project, also unbuilt and without a defined place, is part of these studies of Corbusier's M.A.S.The Maison Clarke Arundell ideal house project (London 1939) is also part of the M.A.S. research, which composed study material for the projects of workers' housing in Lannemezan, France (1940).

These projects created conditions for the adoption of industrial and metallic elements in the construction. Light elements should be easily transported by train and assembled on site. The house, in all its component elements, should be produced industrially, from its structure, walls, windows, doors, and even furniture, in a functional way.

There is, thus, two different versions to the project model of M.A.S. Maison montée à sec. The project, available at the Le Corbusier Fondation, is the one selected for analysis in this study. In the $4^{\text {th }}$ volume of the architect's Complete Work, organized by Willy Boesiger, we can observe a different design with an inverted roof. The text emphasizes the fact that the project envisaged metal construction with prefabricated and standardized elements such as stairs, doors, windows, and even bathroom and kitchen facilities.

In the Maison Minimum's project, we can observe Corbusier's research on the minimum house, for serial construction. In this project there is an important characteristic of Le Corbusier's architecture: the free plan. Even dealing with a design with a minimum area, the architect created a free and generous space. The free plan happens mainly due to the adoption of movable partitions that change position by day or night. The feeling of spaciousness is enhanced by the partitions whose height do not reach the ceiling, providing fluidity to the
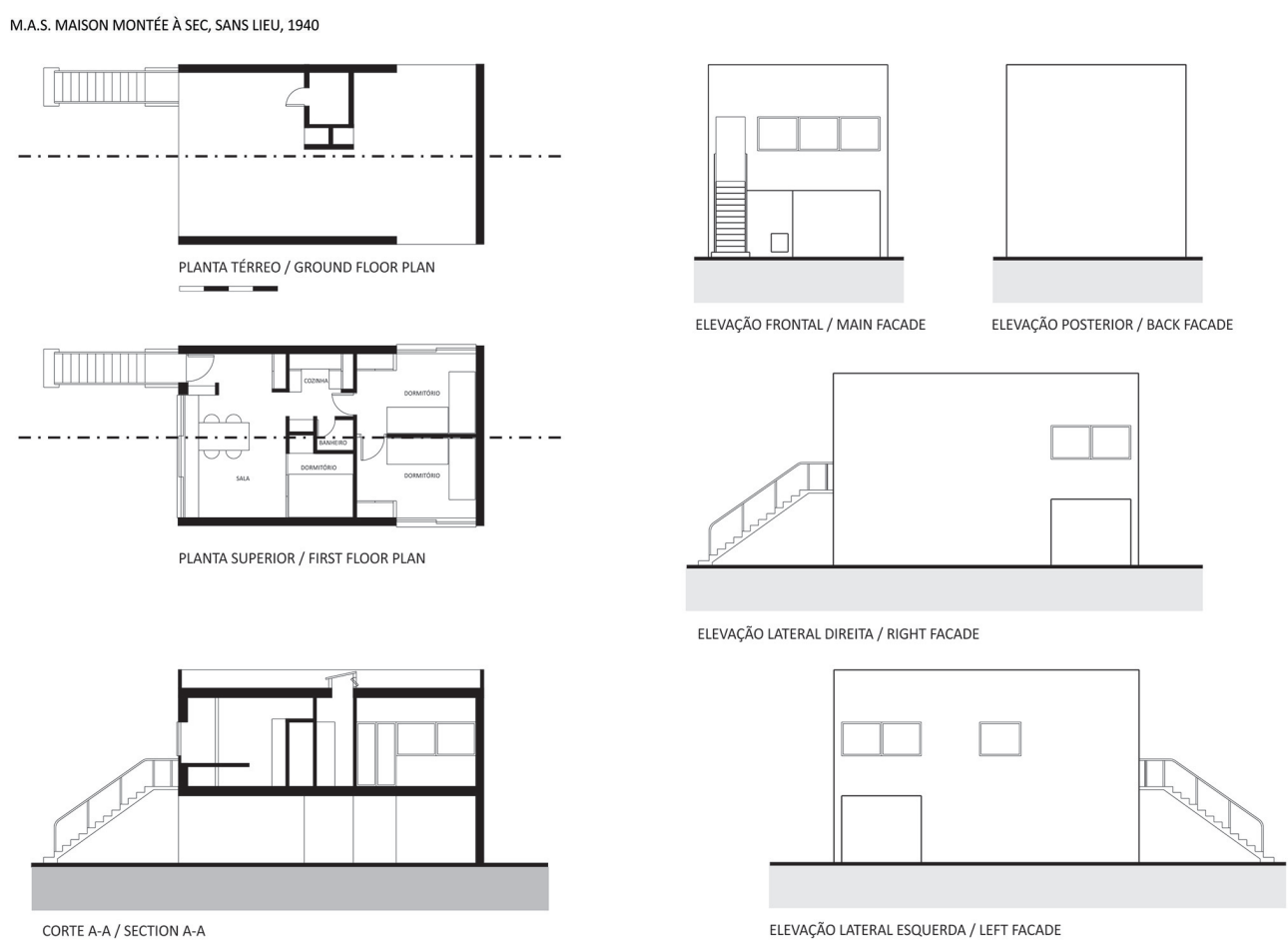
space. During the two-dimensional redrawing phase (fig. 2) we identified these two characteristics that can be observed in several of the analyzed projects. Corbusier represents the plan for day and night, with the suggested changes. The ground floor can be considered a semi-public space, where the family gathers for leisure activities close to nature. In addition, living on the upper floor creates the feeling of safety and hygiene.

All furniture was designed by the architect in a unique way with the housing project. There is no distinction between both designs (furniture and architecture), unlike other architects who believed that each project should have unique furniture, as noted by Stanilaus von Moos [1979, p. 53].

The idea offers flexibility for combinations, which provides a way to customize each project, even if it is industrialized, prefabricated, and to be mass produced.

As Adolf Max Vogt [1998, p. 9] noted concerning the five points of Corbusier's new architecture, there was a rejection, by the architect, concerning the ground floor and basement, considered damp and dark. Raising the house with pilotis would promote hygiene and also create a pedestrian circulation space and play area for adults and children. Corbusier believed in the freedom of the ground floor for people to walk without interruption. It is a vision of a democratic society and a civilized city, without walls or bars.

The plan's geometry is rectangular. Corbusier creates a flat wall on the back forefront, so there is the possibility of combination, preserving the privacy of the inhabitants. The pure form is in harmony with the architect's language. Simple and stripped of ornaments and with an industrial character.

The three-dimensional analysis based on 3D digital Model as well as the physical model (fig. 3) allowed us a full understanding the relations between forma and space, architectural elements, and also possibilities of combination and grouping.

Fig. 5. Maison Montée a sec (1940). Physical model. Source: author.
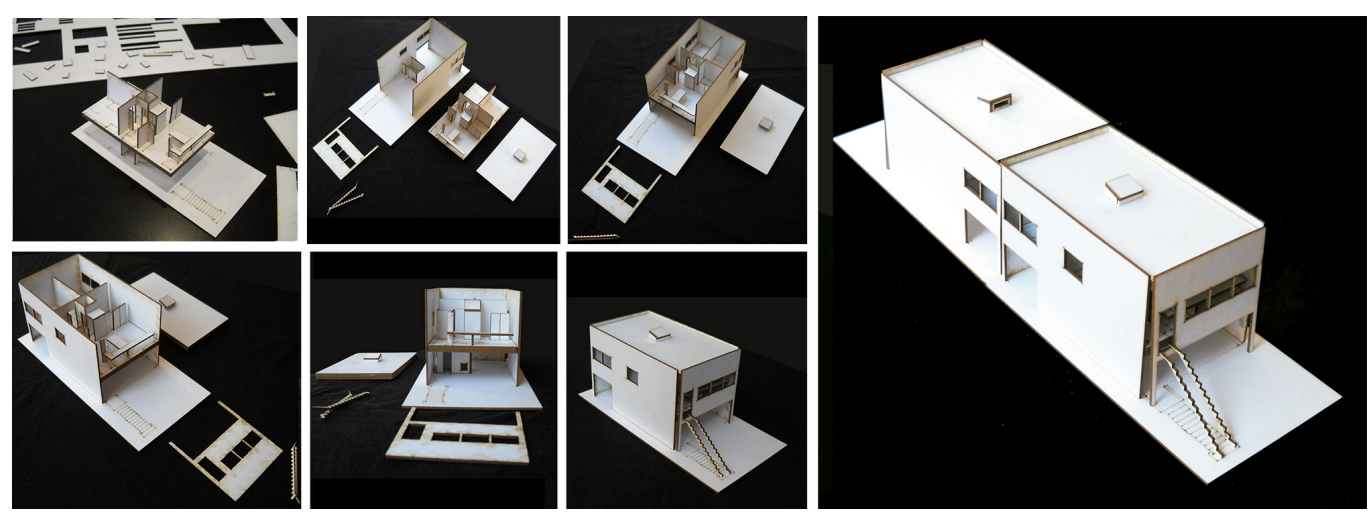

Maisons Type La Rochelle (1953)

In this design (figs. 6-9), a different direction is observed from the other designs for serial construction. While the design of the Maison montée à sec provided for a paired combination with only one blind wall, the design of the Maison Type La Rochelle features two blind side walls allowing for more combinations, side by side. A row house type.

The Transitoires Housings (1944) design presents a similar way of grouping. In this project, we can visualize the combination of the main design idea of Maison montée à sec and Maison Type La Rochelle. A housing project to be built quickly and economically.

Each unit has its architectural program organized in two floors, with sectors distributed in an unconventional way. The intimate sector is distributed on the two floors, while the social and service sectors are located on the upper floor.

The space for recreation and rest is important, and are located on the ground floor, in the front and back, in the configuration of a garden; on the upper floor two terraces with hollow elements for ventilation are proposed, similar to the terrace of the building housing unit in Marseille. 
The issue of light and natural ventilation is a reason for study to Corbusier. The unit was designed with generous windows, terraces, and a clerestory-like upper opening to illuminate and ventilate the social sector, kitchen, and circulation.

This project proves to be suitable for houses for serial construction, especially due to the blind walls that allow the combination and organization of multiple groups of units without losing the privacy and individuality of each user.

In Corbusier's original perspective, we can observe a way to combine the units, creating an "L" shape (fig. I0), configuring a central common area.

MAISON TYPE LA ROCHELLE, SANS LIEU, 1953

Fig. 6. Maison type La Rochelle (1953) redrawn. Source: author.

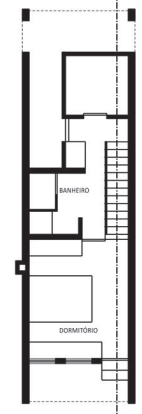

PLANTA TÉRREO GROUND FLOOR P - -
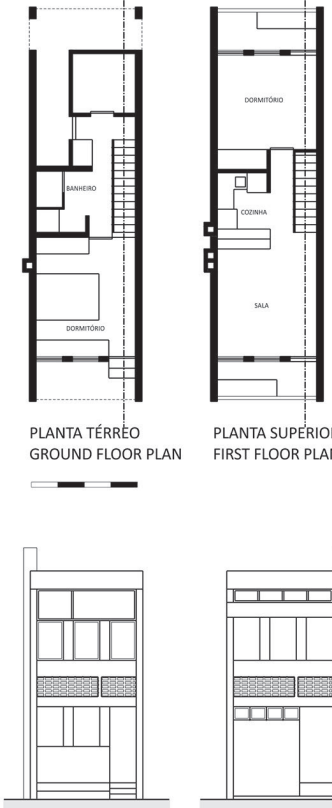

PLANTA SUPERIOR FIRST FLOOR PLAN

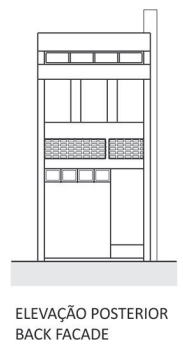

ELEVAÇÃO FRONTA MAIN FACADE BACK FACADE

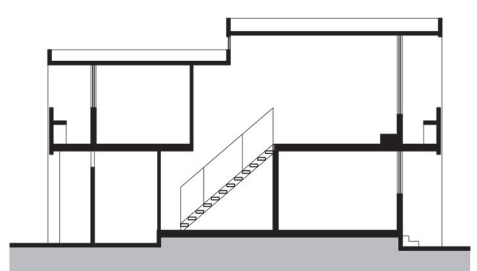

CORTE AA / SECTION AA

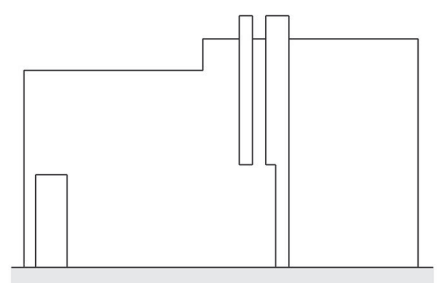

ELEVAÇÃo LATERAL ESQUERDA LEFT FACADE

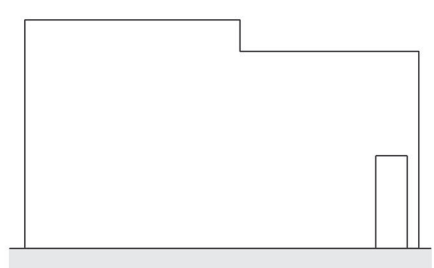
ELEVAÇÃO LATERAL DIREITA
RIGHT FACADE
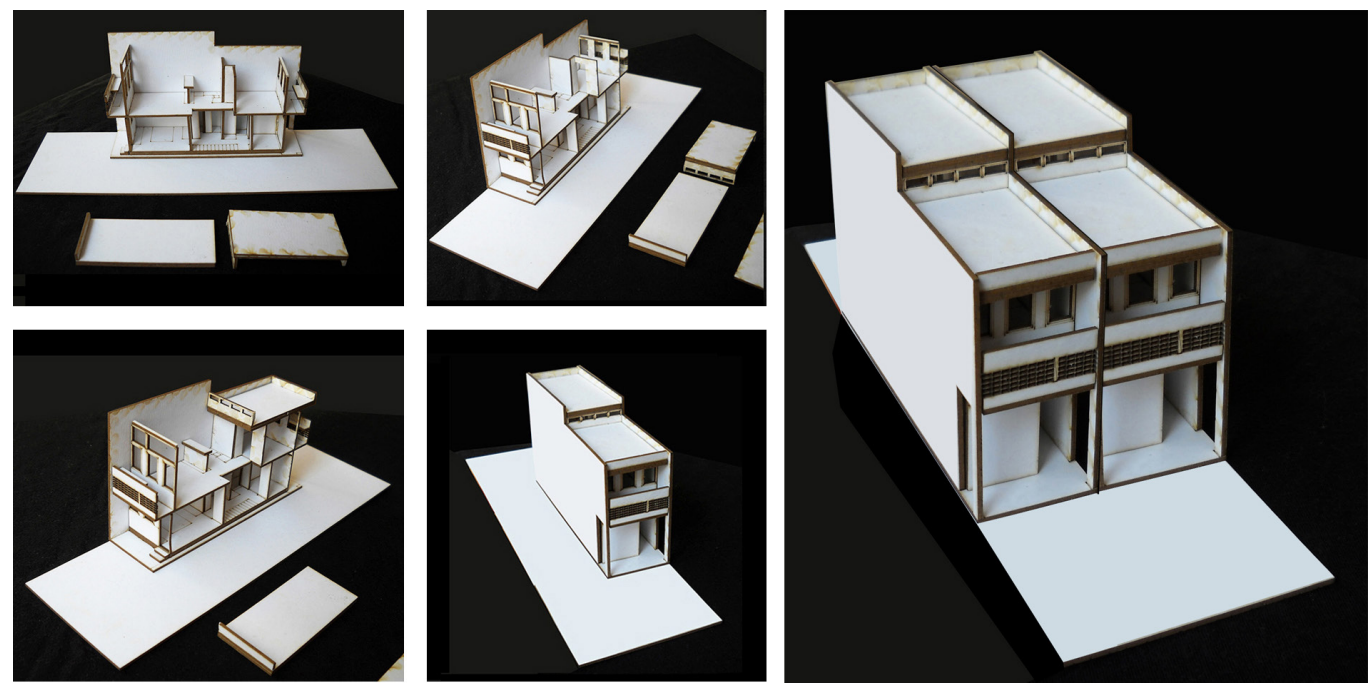
Fig. 8. Maison type La Rochelle (1953). Digita Model. Source: author.
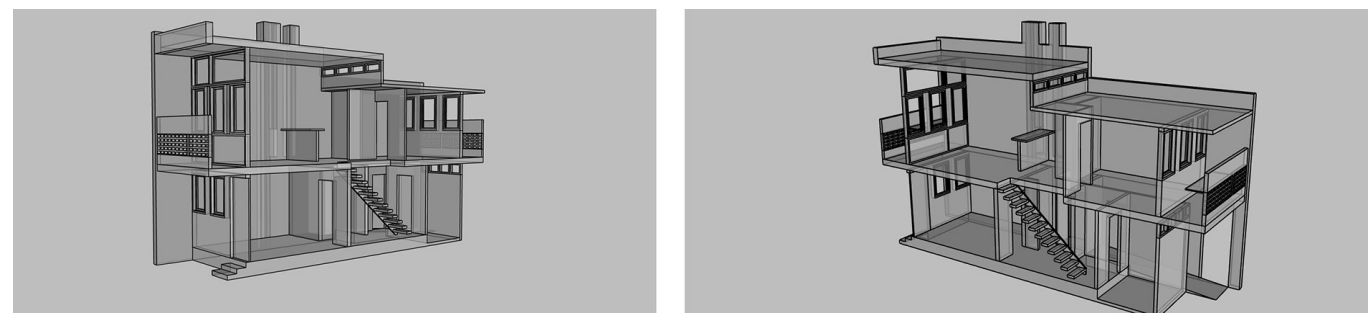

\section{Discussion}

Results involving design analysis indicated unknown solutions to the problem of the minimum housing unit to be built in series. We understand that this knowledge is important to be studied and discussed, especially regarding the issue of modern and contemporary housing and new technologies.

The digital reconstruction of drawings and models of these projects allows us not only to reconstruct graphical elements and physical artifacts, but to analyze, evaluate, and highlight characteristics and values not easily recognizable just by looking at the files.

The drawings of the projects selected in this research (maisons sans lieu) reveal important characteristics and results of Le Corbusier's research on the design and construction of collective housing, minimum unit, and serial construction. We can highlight the following attributes from the investigation, that made it more visible from the redesigns and digital models supported by new technologies:

1. Designs that foresee prefabricated elements for construction, a fact that allows for a more economical and fast construction, as we can see in the Maison à sec;

2. Different ways of organizing the minimum residential program, creating possibilities for combing the units;

3. We can note different strategies on how to create a project concerned with ventilation and sun light in different situations.

4. Design of all the elements that make up the space, from furniture, frames, stairs, door, window, among others.

5. Concern with the creation of spaces for leisure and rest, besides the privacy of users;

6. How to design a good minimum residential space. If modern cities offer everything we need, there is no need to inhabit large spaces.

We note that some architectural elements and space and environment solutions, such as balcony, terrace, hollow element, double ceiling height, furniture, industrialized staircase, and sliding doors, form a great repertoire of ideas, anticipating solutions and enriching the project of minimum collective housing unit.

The incessant search for new architectural solutions combined with new building technologies in modern times.

Regarding the adopted methodology, we can conclude that the mountable physical models contributed in a fundamental way to the understanding and analysis of the projects, since
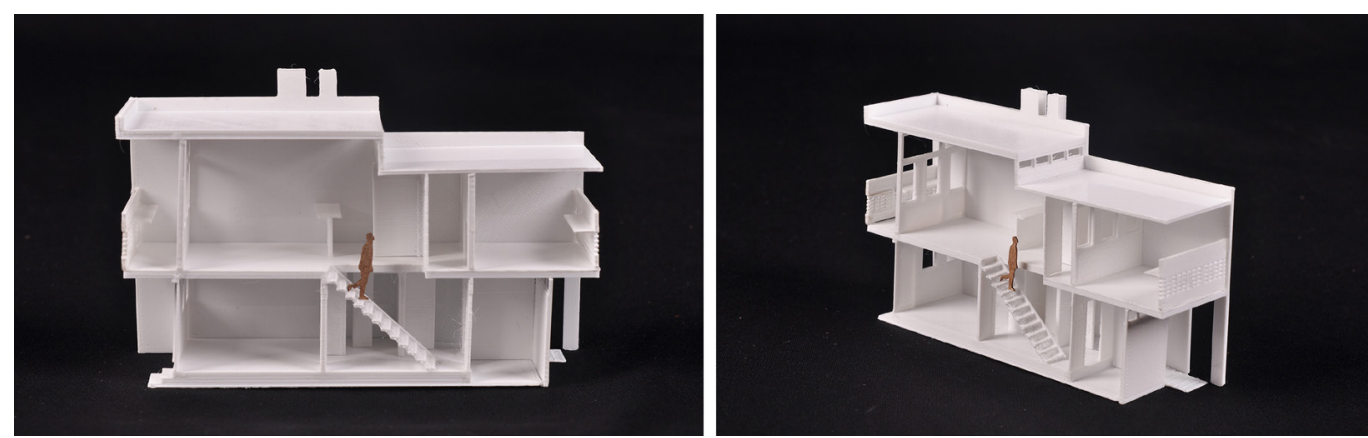

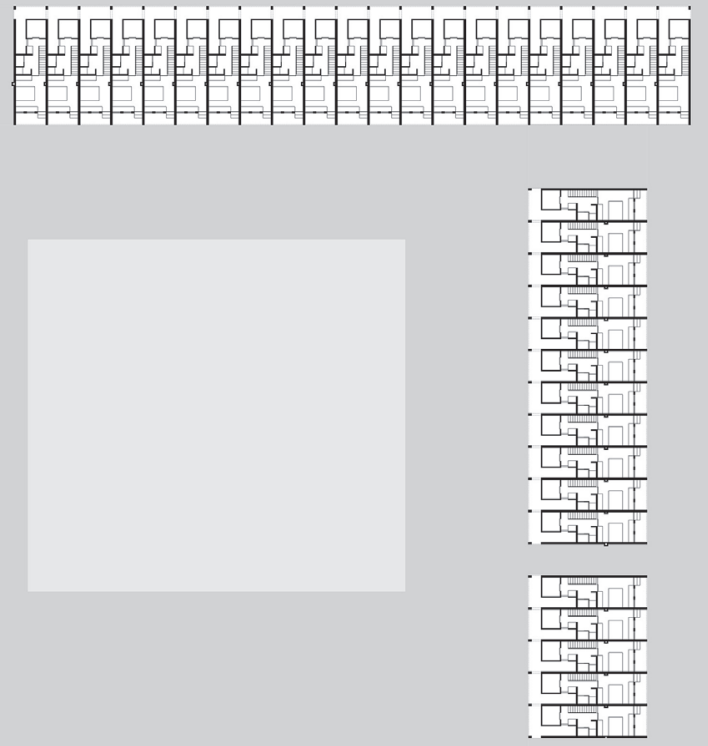

the scale model can be decomposed, allowing to visualize the spatial relations, internal and external, between different sectors. The obtained results indicate that the physical scale models contribute to the deepening of the investigation of unbuilt projects, from the conceptual and aesthetic point of view, as well as the functional and technical views. This methodology contributes substantially to pedagogical practices, in which physical scale models help to interpret the dilatations and contractions of spaces, full and empty, and their relationships with structure and coverage. Therefore, in the absence of the built work, the model produced by digital technology approaches the materiality of the physical environment, a fundamental aspect for the investigation of unbuilt projects.

From the above, we believe that the adoption of this method contributes to a deeper analysis of projects, as it allows to interpret, evaluate, and synthesize fragmented information. In addition, we hope to contribute to the dissemination and development of new architectural teaching and learning processes using the new tools provided by new technologies.

Through the development of this research, we were able to highlight some hypotheses raised at the beginning, and also during the development of the research. The study of the selected projects, unbuilt and without defined place, contributes to a better understand-
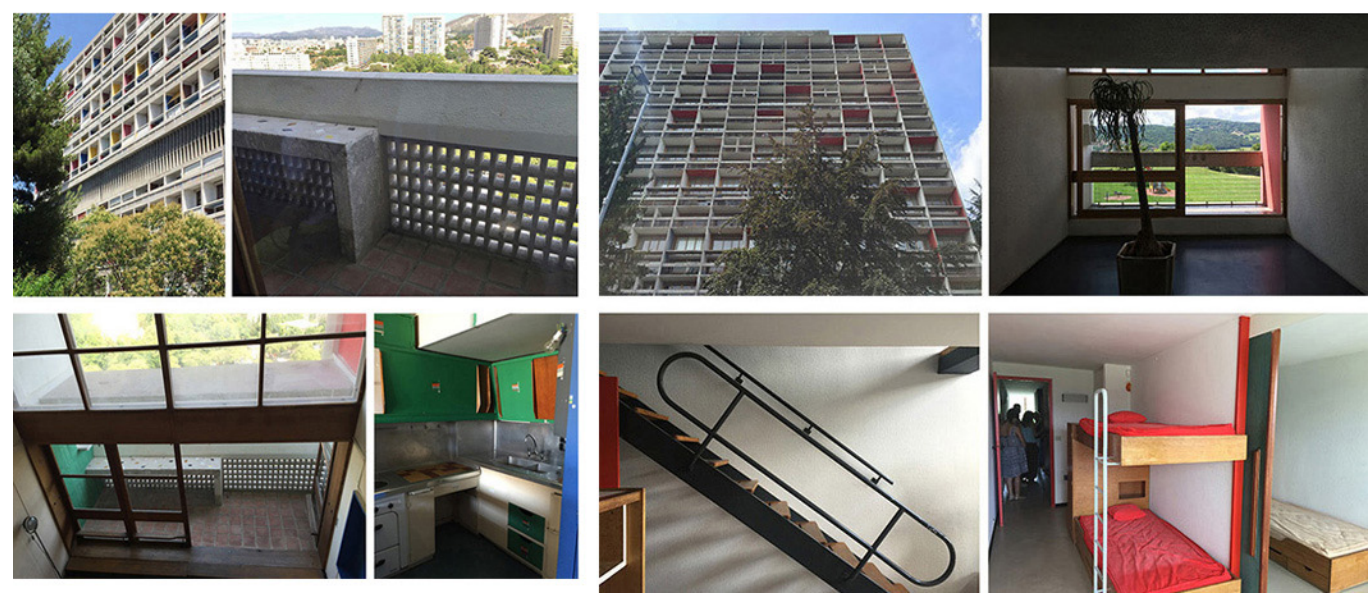

Fig. I I. (left): Unité d'Habitacion in Marseille. (right): Unité d'Habitacion 2016. 
ing and comprehension of Le Corbusier's oeuvre, especially in the subject of housing and serial production. The research also revealed that the methodology adopted for the study of these projects, using analytical diagrams and physical scale models, was fundamental to achieve the intended results.

Corbusier has incorporated innovative concepts for residential design. His unique vision of the modern world, and his intense work, contributed to enhancing the repertoire of solutions on collective housing and serial production.

Some of Corbusier's projects can be considered visionary because the architect's ambition was not to respond to present problems, but to point new directions to the architecture of the future. His proposals were not answers to specific problems, but experiments and reflections on how to move towards new values and concepts of modern society.

Studying Corbusier's architecture through his drawings, we can see his involvement with the technologies of his time. With his positive stance concerning new technologies and modern life. As we can see, good ideas are timeless and surpass their time, without losing their validity.

The research results indicate that, from the original design, the research developed within the digital contexts contributes to a deeper understanding of the selected projects, from conceptual to aesthetic, functional and technical aspects. In addition, in the absence of the built architecture, the physical and digital models, conceived from the new technologies, address the materiality of the physical and tactile appeal, fundamental to the investigation of unbuilt projects.

Thus, from this study, it can be noted that unbuilt projects contribute to a better understanding of the set of residential oeuvre designed by Le Corbusier. This research aimed to provide an up-to-date insight into the work of this important architect, exploring the potential of research in digital contexts. We believe the impact to the knowledge area is scientific, cultural, and educational.

\title{
Acknowledgments
}

CAPES Print, CNPq, and Fundo MackPesquisa for the financial support.

\section{References}

Cohen J. L., Benton T. (2014). Le Corbusier. Le Grand. London: Phaidon Press.

Curtis W. J. R. (1986). Le Corbusier. Ideas and Forms. London: Phaidon Press.

Galli M., Mühlhoff C. (2000). Virtual Terragni. CAAD In Historical and Critical Research. Basel, Boston, Berlin: Birhäuser.

Larson K. (2000). Louis I. Kahn. Unbuilt Masterworks. New York:The Monacelli Press.

Le Corbusier, BoesigerW. (1936). Le Corbusier et Pierre Jeanneret. Oeuvre Complète. Zurich: Lés Éditions D'Architecture.

Park S. (2012). Le Corbusier Redrawn. The Houses. New York: Princeton Architectural Press.

Sdegno A. (20 I 0). Digital Simulation of the City forThree Millions Inhabitants by Le Corbusier. Geometrical analysis, electronic reconstruction and video Animation. In G. Schmitt et al. (Eds.). eCAADe 2010.28 $28^{\text {th }}$ Conference Future Cities. Proceedings of the 28th Conference on Education in Computer Aided Architectural Design in Europe. Zürich, I5- 18 settembre 20 I0, pp. 549-556. Zürich: vdf Hochschulverlag AG an der ETH.

Fondation Le Corbusier <http://www.fondationlecorbusier.fr> (accessed 2020, November 23).

\author{
Authors \\ Ana Tagliari, University of Campinas, tagliari.ana@gmail.com \\ Wilson Florio, Mackenzie Presbyterian University, wilsonflorio@gmail.com
}

To cite this chapter. Tagliari Ana, Florio Wilson (2021). Le Corbusier's Maisons sans lieu. Reconstructive redrawing, digital and physical model of unbuilt architecture. In Arena A., Arena M., Mediati D., Raffa P. (a cura di). Connettere. Un disegno per annodare e tessere. Linguaggi Distanze Tecnologie. Atti del $42^{\circ}$ Convegno Internazionale dei Docenti delle Discipline della Rappresentazione/Connecting. Drawing for weaving relationship. Languages Distances Technologies. Proceedings of the $42^{\text {th }}$ International Conference of Representation Disciplines Teachers. Milano: FrancoAngeli, 1 I 79 - I 187. 